\title{
A DEVELOPED POTATO PLANTER FOR MINIMIZING POTATO TUBER MOTH AND GREENING
}

\section{Abd El-Maksoud M. A." Gomaa A.H. $\quad$ Abd El Fattah H. A** \\ ABSTRACT}

The maximum prevention control for both moth to reach tubers and exposure tubers to light mechanically through the constructed shape of the potato hill by each potato planter was the main aim of this study. For this purpose the performance of a modified potato planter, equipped with designed bedding unit (Batana) was investigated. The investigation was accomplished through comparison with other two automatic common used potato planters. Nicola, Spunta and Lady Rosetta potato seed varieties under drip irrigation at planting spring season cultivated in sandy soil within planting distance intra-row of $25 \mathrm{~cm}$ and planting depths 3, 5, $7 \mathrm{~cm}$ from soil surface were the material cultivar of the investigated planters. The performance evaluation included mechanical as well as work rates at different planting speeds for the compared planters and yield components. The mechanical performance included (total traction force in $\mathrm{kN}$ and total power in $\mathrm{kW}$, fuel and specific fuel consumption in $L / h$ and $L / k W . h$, tractor drive wheel slip in $\%$, field capacity in $\mathrm{fed} / \mathrm{h}$ and efficiency in \%) as an average values. Yield components included the total tuber yield, tuber moth infestation and tuber greening in ton/fed.

\section{BACKGROUND}

7 he greening of the potato tuber is associated with forming the glycoalkaloids solanine and chaconine concentrated under the 1 skin, which have toxic properties (Brown and Keeler 1978). Concentrations of the glycoalkaloids vary according to environmental conditions during growth, particularly exposure to light as well as genetic factors (Jadhav \& Salunkhe 1975). Also the potato tuber moth (PTM), Phthorimaea operculella (Zeller) is the most important potato pests in warm temperate and tropical areas.

\footnotetext{
* Assoc. Prof. of Ag. Eng. Dep. Fac. of Agic. Menoufiya U., Egypt. ** Eng. of Ag. Eng. Plant Protection Res. Center, Egypt.
} 
It is the number one pest of potato throughout the Middle East and North Africa. It damages both foliage and tubers. In Egypt populations are low during the cold and rainy winter period, but increase to significant levels during the hot and dry summer months. In the field, the potato tuber moth can damage up to $25 \%$ particularly if the harvest is delayed but in storage it can damage $100 \%$ of the tubers (Hanafi 2004).

Toader and Draica (1983), Talburt, and Smith (1987) and Abou ElMagd (2001) reported that the choice of potato planting system is of great importance that is because environmental conditions are greatly influencing potato production quantity and quality. Peter (1990) outlined the criteria for evaluating potato planter performance as field efficiency and work quality, other factors such as planting performance and seed crop size and shape are important. Potatoes are generally grown on ridges. Ridges have the advantage that planting dose not have to be done too deeply, while later in the season a ridge can be built up to ensure that the developing tubers are covered with an adequate layer of soil. Bishop and Maunder (1980) and CIP (1993) showed that the ideal potato ridge width ranges from 0.65 to $0.90 \mathrm{~m}$. They added that the row might have a cross-sectional area of about $0.075 \mathrm{~m}^{2}$ and the distance within the row depends on other factors such as the yield, variety of potatoes, and type of soil. They concluded that row width of about $0.75 \mathrm{~m}$ and distance within the row ranging form 0.25 to $0.30 \mathrm{~m}$ result in a satisfactory yield.

Jarvis and Palmer 1973, El-Shal and Shehata (1987), Chmielnicki (1988) and Ismail (1991) stated that depth of planting has an effect on yield and deep planting may reduce total yield. Depth of planting should be adjusted according to the soil conditions. Generally, they concluded that variations in depth within the normal range of $0-7.5 \mathrm{~cm}$ below ground level appear to have little effect. In this aspect the tubers should be covered with sufficiently deep layer of soil to protect the tubers from direct light (which causes them to become green), from high temperature (second growth) and from insect damage (tuber mouth). Zaag et al. (1987) reported that double-row beds enhanced yields by up to 3 ton/ha over single row ridges. They pointed out that shallow planting gave faster emergence and canopy development but it did not improve yields, and 
resulted in more greening tubers. Kistanov and Oshurkov (2001) used 70,75 or $90 \mathrm{~cm}$ between rows, forward speed of $0.56-1.89 \mathrm{~km} / \mathrm{h}$, and tuber spacing in the row of 35,70 or $105 \mathrm{~cm}$. Planting depth was $4-12$ $\mathrm{cm}$. The corresponding plant density was 20000-40000 tubers/ha. Mir (2006) evaluated potato planter performance by seed spacing, planter speed, and seed depth. He pointed out that planter speed had consistent importance for achieving good planter performance. Todar and Draica (1983) found that with mechanical planter, the speed of $5 \mathrm{~km} / \mathrm{h}$ is recommended to achieve uniform distribution of tubers within the row at recommended depth of 10-12 cm. According to Siemens and Bowers (1999) fuel consumption is expressed as specific volumetric fuel consumption (L/kW-h) which is generally not affected by engine size and pointed out that for diesel engines typically it ranges from 0.24 to 0.56 L/kW-h. Helsel and Oguntunde(1985) summarized fuel consumption values for many field operations and reported that the average value for potato planter ranged from 3.74 to $7.47 \mathrm{~L} / \mathrm{fed}$. Awady et al. (1993) reported that the planting machine slippage caused greater increase in missing hills, and hills spacing, they added that slippage percent increased with the planting depth. According to ASAE (1992) the slip percentage can be determined from the following formula:

$$
\mathrm{SL} \%=(\mathrm{VT}-\mathrm{VO}) / \mathrm{VT} \times 100
$$

Where:VT $=$ theoretical traveled speed $\mathrm{m} / \mathrm{s}$,

$\mathrm{VO}=$ actual operating speed $\mathrm{m} / \mathrm{s}$,

The objective of this work was to discover means of mechanical preventing access of PTM larvae and light to tuber before harvesting through a comparative study of the performances of a modified automatic potato planter attached with bedding tool called (Battana) designed for this purpose with two other ridge planters of the same type.

\section{MATERIAL AND METHODS}

\section{1- Potato planters}

The developed two rows automatic potato planter $\left(\mathrm{M}_{1}\right)$ components including the main operating elements to suit the bed system of planting is shown in figure (1). 

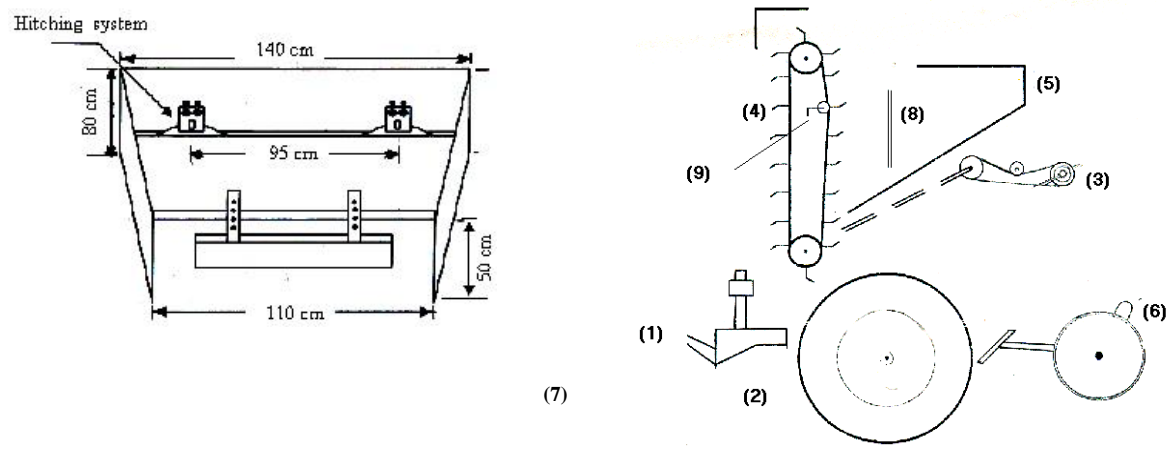

Figure (1): Developed potato planter with bedding system

1-Furrow opener, 2-Drive wheel.,3-Feeding mechanism.,4-Cup conveyer belt.,5-

Hopper., 6-Covering discs.,7-Bedding unit.,8-Adjustable supply slide.and 9-Vibrator.

It can be fitted on the tractor using the three hitching points system. All its components were manufactured and modified locally as shown in figure (2).
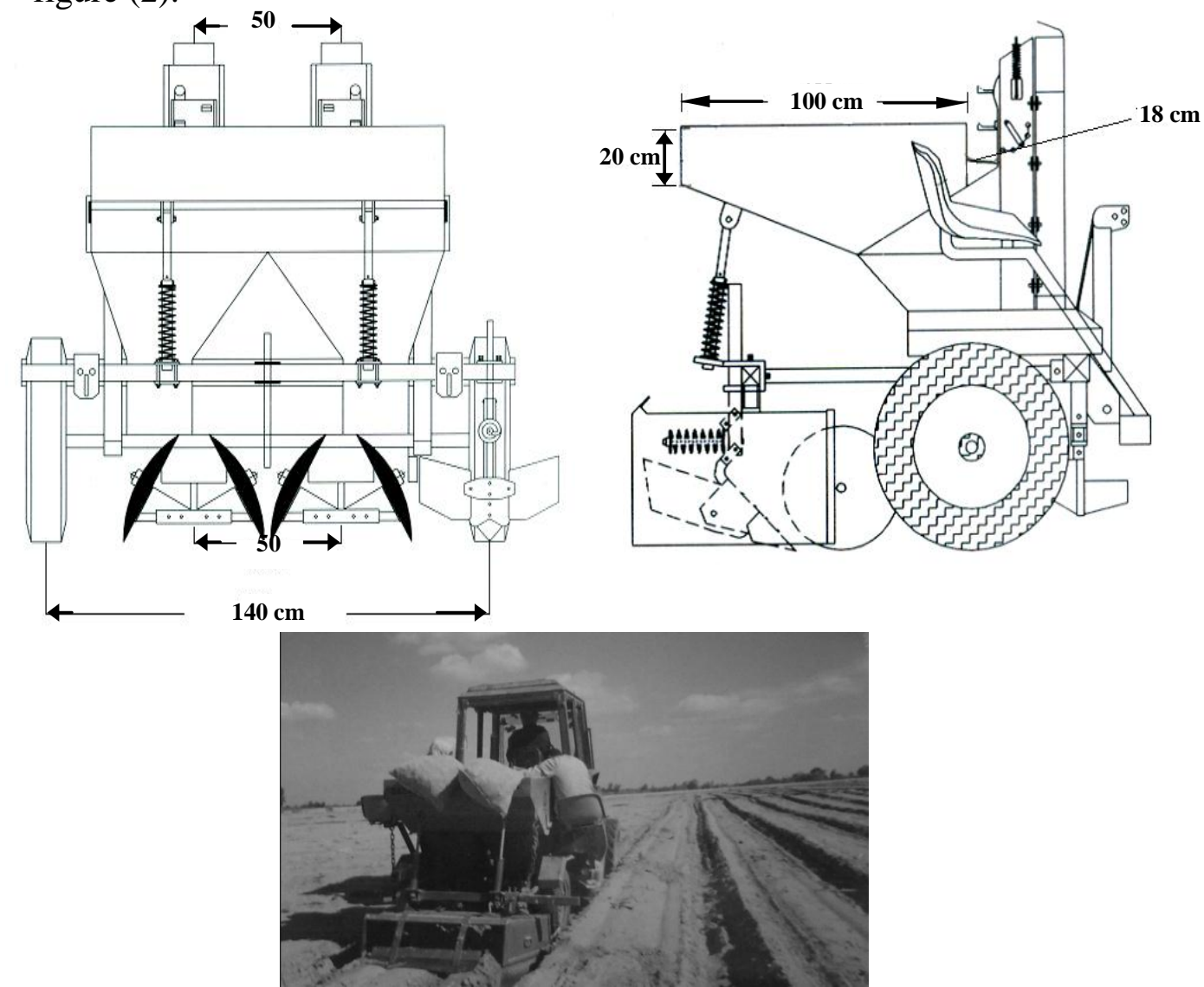

Figure (2): Elevation and side view of the developed potato planter $\left(\mathrm{M}_{1}\right)$ 
The modification procedures of the potato planter included the main operating elements such as: the tuber seed tank and the positions of the formation ridging units. Furthermore, six main units included the furrow opener, covering discs, transmission system, tuber seed hopper, hitching system and the frame attached as a bedding unit with the design specifications as shown in figure (3). It was regarded that this planter can be fabricated from locally available materials and not requiring sophisticated fabrication techniques in addition most of the materials utilized in the fabrication are of the standard size and are readily available in any locality. The present study included also two other automatic two- rows potato planters $\mathrm{M}_{2}$ and $\mathrm{M}_{3}$ of the same type but differ in ridge formation (hill or normal pyramid shape)and used in comparison with the developed planter $\mathrm{M}_{1}$. The distance between discs which adjusted to produce fair hills with uniform cover in all soil conditions is selected on the basis of inter-row spacing. In $\mathrm{M}_{2}$ it was $75 \mathrm{~cm}$, in $\mathrm{M}_{3}$ it was $90 \mathrm{~cm}$ and with the bed unit it was available for 40,45 and $50 \mathrm{~cm}$ as shown in Figure (4).
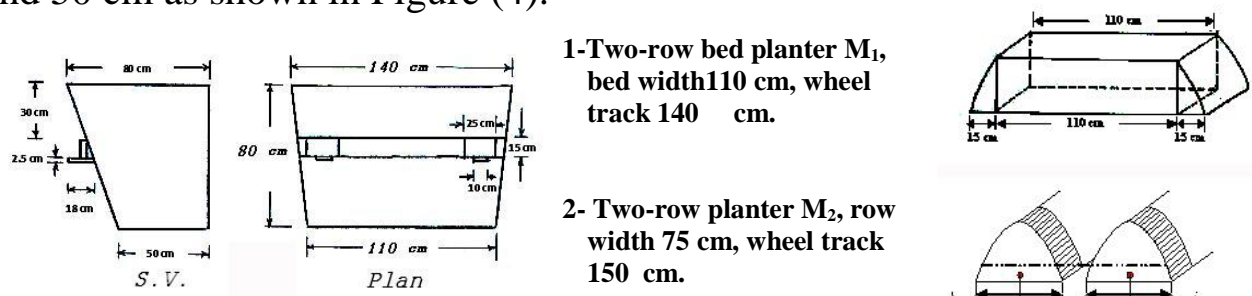

2- Two-row planter $M_{2}$, row width $75 \mathrm{~cm}$, wheel track $150 \mathrm{~cm}$.

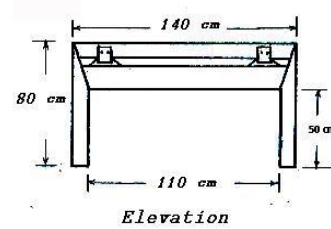

Figure (3)

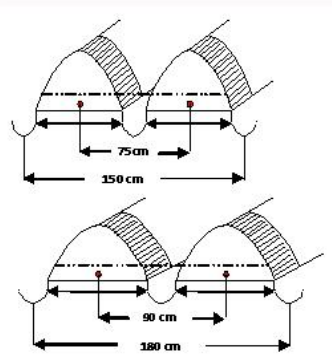

Figure (4)

Figures (3\&4): Bedding unit of the developed potato planter $\left(\mathrm{M}_{1}\right)$ Planting and row formation systems of the planters $\mathrm{M}_{1}, \mathrm{M}_{2}$ and $\mathrm{M}_{3}$

\section{2-Tractors}

Two diesel tractors were used especially for traction force determinations (Landini 2 wheel drive and Landini 4 wheel drive, $64.17 \mathrm{~kW}$ each). 


\section{3- Tested soil characteristics}

The soil texture of the soil was sandy with the gradients of mechanical analysis (854 sand, 54silt, 92clay- $\mathrm{g} / 1000 \mathrm{~g}$ soil-).

\section{4- Tuber seeds properties, numbers and plants}

Potato (solanum tuberosum L.) Nicola, Spunta and Lady Rosetta varieties were used in the present study. Seeds were graded before keeping in the cold store to a size of $40-50 \mathrm{~mm}$ as a proper size and shape for the given size of planter's cells. Kepner et al.(1986), stated that smooth seeds approaching spherical tuber shape are best adapted to precision planting. Ebubekir (2005) found that seed tuber distribution pattern in the row was distributed as tuber size and machine forward speed increased.

The average mass of different potato seed tubers was $40 \pm 10 \mathrm{~g}$ and recommended by Ismaiel and Abo El-Magd (1994) to suite the different potato planters and for high percentage of emerged plants. The main dimensions, length, width and thickness, of the previous seed tuber varieties were $58 \pm 3,40 \pm 2,35 \pm 2 ; 55 \pm 3,48 \pm 2,40 \pm 2$ and $40 \pm 2,40 \pm 2$, $40 \pm 2 \mathrm{~mm}$ respectively. Seed tubers, whole seeds, were 1000, 900, and $750 \mathrm{~kg} /$ fedan for $\mathrm{M}_{1}, \mathrm{M}_{2}$ and $\mathrm{M}_{3}$ planters and the average number of plants was 24000, 22400 and 18660 per fedden in case of planting space of $25 \mathrm{~cm}$ respectively. The number of plants $/ \mathrm{m}^{2}(\mathrm{~Np})$ was determined as the following due to the wheel track related to each potato planter:

$\mathrm{Np}=2$ rows $/($ wheel track, $\mathrm{m} \times$ intra-row planting distance, $\mathrm{m}$ )

\section{5-Fuel measuring tank}

Fuel consumption was measured by L/h using a small auxiliary tank of about 4 liters capacity as fuel meter connected to the tractor fuel tank during each concerned plot experiment figure (5-A). This measurement accomplished in the field practically by filling the fuel tank of the tractor before and after finishing each experimental operation, noting the area covered. The number of liters used, divided by the area covered, gives the fuel consumption in liters per unit area (L/feddan).

\section{6- Spring dynamometer}

Total traction force, net force and rolling resistance data were measured by the method recommended by ASAE (199r) when a spring dynamometer developed by El-Sheikha (1989) used after its calibration as shown in figure (5-B). Hence in each plot of each experimental 
treatment, the planter was mounted on the main tractor and pulled by another one. The tensile forces were then measured as the horizontal component of the force between the driving tractor and the main tractorcombination. In this direction, rolling resistance was defined as the force required for moving both the main tractor and potato planter over tested plots when the planter was in lifted position. Total traction force was the recorded reading by the spring dynamometer between the two tractors (the main and the driving) when each planter was in forming and planting position of two rows at the specified plot under the concerned conditions of the experiment. Then the net force was calculated as the difference between both the total traction force and the rolling resistance in $\mathrm{kN}$.

\section{7-Other instruments}

Tachometer, It was used to measure the rational speeds.

Balance, It was used to measure the weight of tubers resulted from the tested treatments and their replicates.

Steel tape, It was used to measure the length of the planter tracks, traveled distances, lengths of the tested plots, distance between the hills and dimensions of tuber distribution in the row.

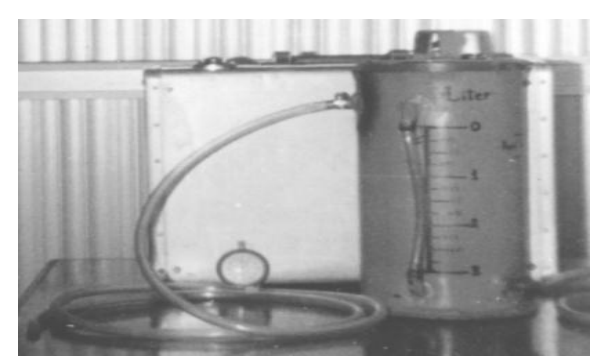

Figure (5): A-Fuel measuring tank

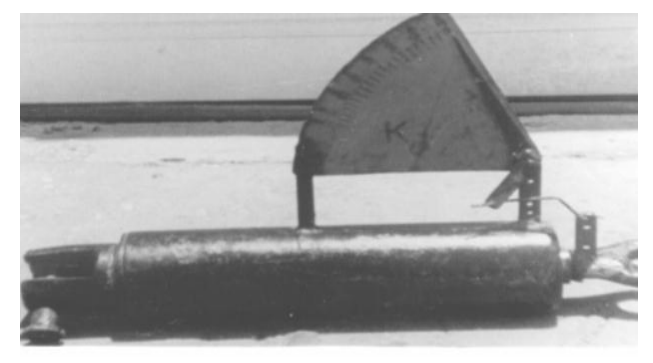

B- Spring dynamometer

\section{Experimental procedures}

The experiments of the present study were carried out during growing spring season at El Bustan, El-Noubaria region. The texture of the soil was sandy as mentioned before. Soil was ploughed before planting followed by cultivation, additional animal manure, chemical fertilizer application and two more plough runs to insure a good seed bed. Ridges 
(two row distances) were prepared within the distance of $140 \mathrm{~cm}$ for $\left(\mathrm{M}_{1}\right) ; 150 \mathrm{~cm}$ for $\left(\mathrm{M}_{2}\right)$ and $180 \mathrm{~cm}$ for $\left(\mathrm{M}_{3}\right)$. A factorial experiment based on randomized complete block design with three replications was conducted in three rectangular shape fields with the area $42 \times 100 \mathrm{~m}^{2}$ for each.

The performance measurements were conducted to investigate the developed planter with the attached bedding unit $\left(\mathrm{M}_{1}\right)$ comparing with the two automatic planters $\left(\mathrm{M}_{2}\right)$ and $\left(\mathrm{M}_{3}\right)$. The mechanical performance and work rates parameters were investigated against five forward speed levels of $3,3.8,5,5.5$ and $7 \mathrm{~km} / \mathrm{h}$, and also against three planting depths 3,5 and $7 \mathrm{~cm}$ from soil surface in sandy soil. These measured and calculated parameters necessary for planting and bed or ridge forming were total traction force (TF), total power requirements (TP) fuel consumption (FC), specific fuel consumption (SFC), slip ratio (SL \%), actual field capacity $(\boldsymbol{f c})$ and field efficiency $(\boldsymbol{f} \boldsymbol{e} \%)$.

To evaluate the productivity and conditions of the yielded potato tubers, samples were collected randomly from different localities in concerned arias with three replications at harvest time. Average total potato yield, potato tuber moth infestation, greening of potato tubers in ton/feddan and in percentages were conducted for sandy soil under different treatments including drip irrigation system, intra-row distance of $25 \mathrm{~cm}$, at forward speed of $5 \mathrm{~km} / \mathrm{h}$ and row distance $75 \mathrm{~cm}$ by $\left(\mathrm{M}_{2}\right), 90 \mathrm{~cm}$ by $\left(\mathrm{M}_{3}\right)$ and 45 $\mathrm{cm}$ by the bed system $\left(\mathrm{M}_{1}\right)$.

\section{RESULTS AND DISCUSSION}

\section{A-Field evaluation of the mechanical and work rate performance}

The mechanical and work rate performance parameters of the potato planters were inspected during using the forming bed system and the two other planting methods in sandy soil as:

\section{A-1-The average traction force (TF)}

The average total traction force values determined for the different planters $\mathrm{M}_{1}, \mathrm{M}_{2}$ and $\mathrm{M}_{3}$ and where an auxiliary tractor combination was used with every planter to form the three investigated ridge shapes and achieving planting operation at five different speed levels 3, 3.8, 5, 5.5, 7 $\mathrm{km} / \mathrm{h}$ and three planting depths $(3,5$ and $7 \mathrm{~cm})$ in three replicates are 
statistically analyzed using multiple regression analysis. The obtained multiple linear regression equations clarify the relation between traction force $(\mathrm{TF}, \mathrm{kN})$ and each of planting speed $(\mathrm{S}, \mathrm{km} / \mathrm{h})$ and at planting depths $(\mathrm{D}, \mathrm{cm})$ as follows:

For $\mathrm{M}_{1}: \quad \mathrm{TF}=6.231+1.903 \mathrm{~S}+0.695 \mathrm{D} \quad \mathrm{R}^{2}=0.962, \mathrm{STD}=0.583$

For $\mathrm{M}_{2}: \mathrm{TF}=10.629+1.703 \mathrm{~S}+0.490 \mathrm{D} \quad \mathrm{R}^{2}=0.972, \mathrm{STD}=0.469$

For $\mathrm{M}_{3}: \mathrm{TF}=11.649+1.806 \mathrm{~S}+0.455 \mathrm{D} \quad \mathrm{R}^{2}=0.965, \mathrm{STD}=0.553$

It can be seen that the total traction resistance has an increasing trend as the forward speed increases for all the tested depths. In the same time the planting depth was combined with a similar but higher effect on the total traction force depending on the soil moved for forming seed bed by each potato planter.

\section{A-2-The required traction power (TP)}

The average values of power requirements for all investigated ridge construction and planting methods were varying linearly with the planting speed. As the planting speed ranged from 3 to $7 \mathrm{~km} / \mathrm{h}$ the power requirements were increased at planting depth $3 \mathrm{~cm}$ in the range from 12.75 to $42.0 \mathrm{~kW}$ at $\mathrm{M}_{1}$ and in case of $\mathrm{M}_{2}$ it was 14.0 to $45.7 \mathrm{~kW}$ and for $\mathrm{M}_{3}$ it was 14.5 to $49.19 \mathrm{~kW}$. That behavior was similar for all potato planters when practicing the two other depths 5 and $7 \mathrm{~cm}$.

Multiple regression equations were conducted to clarify the relation between traction power $(\mathrm{TP}, \mathrm{kW})$ and each of planting speed $(\mathrm{S}, \mathrm{km} / \mathrm{h})$ and at planting depths $(\mathrm{D}, \mathrm{cm})$ :

For $\mathrm{M}_{1}: \quad \mathrm{TP}=-16.947+7.949 \mathrm{~S}+0.983 \mathrm{D} \quad \mathrm{R} 2=0.987 \mathrm{STD}=1.425$

For $\mathrm{M}_{2}: \mathrm{TP}=-14.201+8.281 \mathrm{~S}+0.657 \mathrm{D} \quad \mathrm{R} 2=0.990 \mathrm{STD}=1.251$

For $\mathrm{M}_{3}: \mathrm{TP}=-14.004+8.806 \mathrm{~S}+0.563 \mathrm{D} \quad \mathrm{R} 2=0.997 \mathrm{STD}=0.773$

Comparing the investigated ridge construction and planting planters, based on the power requirements $(\mathrm{kW})$ it can be seen that in case of the two-row $\left(\mathrm{M}_{1}\right)$ planter with row spacing of $45 \mathrm{~cm}$ and the distance between the tractor tiers is $140 \mathrm{~cm}$,it needs the less power than $\left(\mathrm{M}_{2}\right) \operatorname{and}\left(\mathrm{M}_{3}\right)$ respectively.

\section{A-3-Fuel consumption (FC)}

The rate of fuel consumed $(\mathrm{FC}, \mathrm{L} / \mathrm{h})$ during carrying out the three ridge formation and planting methods was measured and recorded. The 
collected data was subjected to statistical multiple regression analysis which yielded the following multiple linear regression equations which clarify the effect of planting speed $(\mathrm{S}, \mathrm{km} / \mathrm{h})$ and at planting depths $(\mathrm{D}$, $\mathrm{cm})$ on the fuel consumed in this operation $(\mathrm{FC}, \mathrm{L} / \mathrm{h})$ as follows:

For $\mathrm{M}_{1}: \quad \mathrm{FC}=2.126+0.582 \mathrm{~S}+0.625 \mathrm{D} \quad \mathrm{R}^{2}=0.922, \mathrm{STD}=0.421$

For $\mathrm{M}_{2}: \quad \mathrm{FC}=0.769+1.098 \mathrm{~S}+0.585 \mathrm{D} \quad \mathrm{R}^{2}=0.947, \mathrm{STD}=0.474$

For $\mathrm{M}_{3}: \mathrm{FC}=1.582+0.922 \mathrm{~S}+0.605 \mathrm{D} \quad \mathrm{R}^{2}=0.890, \mathrm{STD}=0.633$

The results indicated that increasing either operating speed or planting depth gave a sensible increment rates in fuel consumption rates. However this effect was differed according to planting methods by $M_{1} M_{2}$ and $M_{3}$ planters. In this direction, it can be seen that fuel consumption rates were always lower in bed system $\mathrm{M}_{1}$ that might be due to the power required in all different planting depths. A general relationship was found that the forward speed was directly proportional with the fuel rate at all the circumstances related.

\section{A-4-Specific fuel consumption (SFC)}

The specific fuel consumption (SFC) parameter was calculated by dividing each actual fuel consumption value by the corresponding data of the required power. The average values of (SFC) were closest to the normal recommended values for the diesel engine tractors $(0.24$ to 0.56 $\mathrm{L} / \mathrm{kW}-\mathrm{h}$ ) by Siemens and Bowers (1999) at forward speed from 3 to 7 $\mathrm{km} / \mathrm{h}$ and planting depth from 3 to $7 \mathrm{~cm}$.

The SFC was varied from 0.342 to 0.569 and 0.32 to 0.519 and 0.274 to 0.514 when forward planting speed varied from 3 to $5 \mathrm{~km} / \mathrm{h}$ at planting depth of $5 \mathrm{~cm}$ for the three planters $\mathrm{M}_{1}, \mathrm{M}_{2}$ and $\mathrm{M}_{3}$ respectively.

The analysis of specific fuel consumption data were demonstrated by the following multiple linear regression equations as a function of planting speed $(\mathrm{S}, \mathrm{km} / \mathrm{h})$ and planting depth $(\mathrm{D}, \mathrm{cm})$ :

For $\mathrm{M}_{1}: \quad \mathrm{SFC}=0.658-0.081 \mathrm{~S}+0.017 \mathrm{D} \quad \mathrm{R} 2=0.891, \mathrm{STD}=0.045$

For $\mathrm{M}_{2}: \quad \mathrm{SFC}=0.547-0.058 \mathrm{~S}+0.015 \mathrm{D} \quad \mathrm{R} 2=0.877, \mathrm{STD}=0.035$

For $\mathrm{M}_{3}: \quad \mathrm{SFC}=0.540-0.061 \mathrm{~S}+0.015 \mathrm{D} \quad \mathrm{R} 2=0.867, \mathrm{STD}=0.039$ 
The equations clarify that the SFC was inversely proportional with forward speed and directly proportional with planting depth. A reversible effect was noticed between forward speed on each of SFC and FC, while the effect of planting depth was positively the same.

\section{A-5-Tractor drive wheel slip (SL \%)}

The obtained data of slippage as a function of draft force are shown in figure (6) for the three planters $\mathrm{M}_{1}, \mathrm{M}_{2}$ and $\mathrm{M}_{3}$ as affected by planting depth $(3,5$ and $7 \mathrm{~cm})$ and a range of forward speed from 3 to $7 \mathrm{~km} / \mathrm{hr}$. The collected data of slippage was subjected to statistical multiple regression analysis and yielded the following multiple linear regression equations as follows:

$$
\begin{array}{llll}
\text { For } \mathrm{M}_{1} & \text { Slip } \%=-24.0233+3.6875 \mathrm{~S}+3.6150 \mathrm{D} & \mathrm{R}^{2}=0.875 & \mathrm{STD}=3.299 \\
\text { For } \mathrm{M}_{2} & \text { Slip } \%=-23.7012+4.0068 \mathrm{~S}+4.1865 D & \mathrm{R}^{2}=0.920 & \mathrm{STD}=2.905 \\
\text { For } \mathrm{M}_{3} & \text { Slip } \%=-24.1123+4.2079 \mathrm{~S}+4.2750 \mathrm{D} & \mathrm{R}^{2}=0.912 & \mathrm{STD}=3.155
\end{array}
$$

The equations cleared that using the planters $M_{1}, M_{2}$ and $M_{3}$ at high speed of $7 \mathrm{~km} / \mathrm{h}$ exhibited high drive wheel slip percent while planting at $3 \mathrm{~km} / \mathrm{h}$ gave low wheel slip percent especially at planting depths 5 and 7 which affect directly on the maximum available power of the drive tractor used in planting operation. So, the suitable forward speed for the different planters especially at $5 \mathrm{~cm}$ planting depth may be considered 5 $\mathrm{km} / \mathrm{h}$ owing that the slippage should not exceed $15 \%$ for the combination of the potato tractors (Siepman 1983), A remarkable important notice was found, that planting by bed system planter recorded lowest slip ratio average values.

\section{A-6-Actual field capacity $(f c)$}

The effects of planting speed and depth on the actual field capacity $(\boldsymbol{f c})$ are studied. It is obvious that the field capacities of all planters at the same travel speed were decreased with sensible rates by increasing either the planting depth $(3,5$ and $7 \mathrm{~cm})$ or decreasing the 


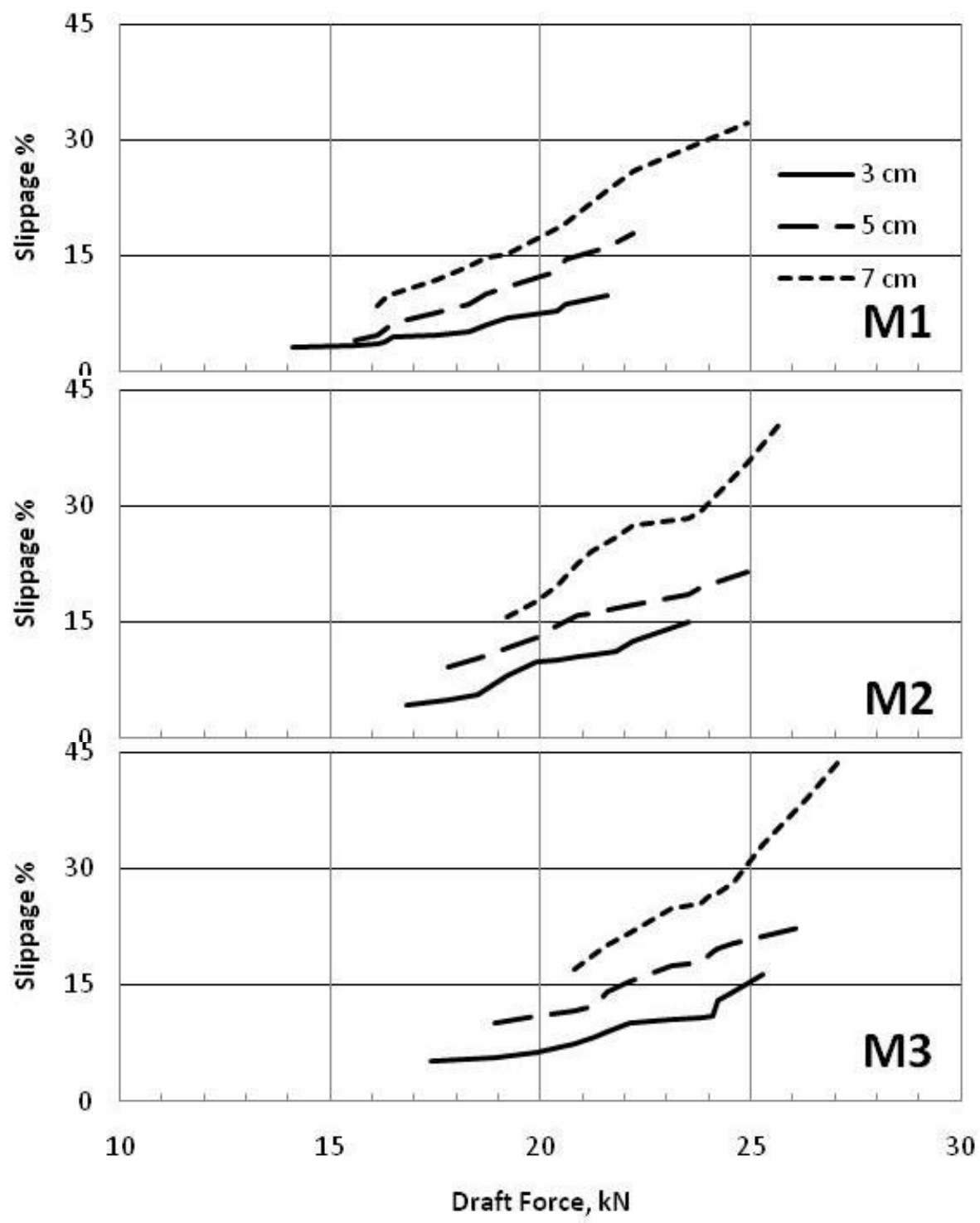

Figure (6): Draft force versus slippage for the three planters $M_{1}, M_{2}$ and $M_{3}$ at different planting speed from 3 to $7 \mathrm{~km} / \mathrm{h}$ and depths from 3 to $7 \mathrm{~cm}$.

essential planting width $(140,150$ and $180 \mathrm{~cm})$ for forming two rows as a self specification related to every planter respectively. In the same time it was noticed that the actual field capacity was directly proportional as general trend with planting speed for all levels of planting depth. Considering the effect of the planting speed $5 \mathrm{~km} / \mathrm{h}$ and the planting depths 3,5 and $7 \mathrm{~cm}$, the actual field capacities were (1.3, 1.2 and 1.1), (1.37, 1.28 and 1.2) and (1.66, 1.54 and 1.43) Fed./h for $\mathrm{M}_{1}, \mathrm{M}_{2}$ and $\mathrm{M}_{3}$. 


\section{A-7-Field efficiency $(f e \%)$}

The obtained average values of the field efficiency related to the performance of the planters $\mathrm{M}_{1}, \mathrm{M}_{2}$ and $\mathrm{M}_{3}$ were inversely proportional with the planting forward speed and planting depth. At forward speed of $5 \mathrm{~km} / \mathrm{h}$ and at planting depth $(3,5$ and $7 \mathrm{~cm})$ the field efficiency were (78, 72 and 66), (77, 72 and 67) and (78, 72 and 67) \% for $\mathrm{M}_{1}, \mathrm{M}_{2}$ and $\mathrm{M}_{3}$ respectively.

\section{B- The productivity and condition of harvested potato tubers:}

The yield and quality of potato tubers production is considered a main goal of the agricultural processes, and is the main factor of the compared potato planter's performance and function. Potato tuber moth infestation, greening of tubers and total yield under drip irrigation system and sandy soil at inter-row planting space of $25 \mathrm{~cm}$ for all planters and row spaces $75 \mathrm{~cm}$ in $\mathrm{M}_{2}, 90 \mathrm{~cm}$ in $\mathrm{M}_{3}$ and $45 \mathrm{~cm}$ in the bed system $M_{1}$ were the main and essential studied parameters.

Data in table (1) represent the average values collected when planting potato seeds for Nicola (N.V), Spunta (Sp.V.) and Lady Rosetta (L.R.V.) varieties which were accomplished at 3,5 and $7 \mathrm{~cm}$ from soil surface at spring season. Figure (7) demonstrates the average data collected in bar drawing. Data represent the resultant performance related to yield and its components of the three previous two- row potato planters. The affected parameters by the previous factors were potato yield as the average values of the infected potato tubers by moth, green tubers and total yield in ton/fed.

Table (1) Average potato production, infestation and greening of different tuber varities planting with M1, M2 and M3.

\begin{tabular}{|l|l|c|c|c|c|c|c|c|c|c|}
\hline $\begin{array}{c}\text { Quality } \\
\text { Parameters }\end{array}$ & $\begin{array}{l}\text { Potato } \\
\text { Variety }\end{array}$ & \multicolumn{3}{|c|}{ Planter (M1) } & \multicolumn{3}{c|}{ Planter (M2) } & \multicolumn{3}{|c|}{ Planter (M3) } \\
\hline & & D1 & D2 & D3 & D1 & D2 & D3 & D1 & D2 & D3 \\
\hline T.Yield(t/f) & N.V. & 18.90 & 18.50 & 17.00 & 17.70 & 16.80 & 16.00 & 17.00 & 16.60 & 16.00 \\
\hline & Sp.V. & 19.60 & 18.50 & 17.20 & 18.00 & 16.70 & 16.00 & 19.00 & 18.50 & 17.00 \\
\hline & L.R.V. & 17.20 & 17.00 & 16.50 & 17.50 & 17.00 & 16.50 & 17.00 & 16.80 & 16.30 \\
\hline PTM (t/f) & N.V. & 0.189 & 0.111 & 0.000 & 1.416 & 0.588 & 0.480 & 0.680 & 0.332 & 0.080 \\
\hline & Sp.V. & 0.235 & 0.074 & 0.000 & 1.800 & 0.585 & 0.400 & 0.380 & 0.111 & 0.034 \\
\hline & L.R.V. & 0.052 & 0.000 & 0.000 & 0.700 & 0.680 & 0.330 & 0.051 & 0.034 & 0.000 \\
\hline G. (t/f) & N.V. & 0.246 & 0.148 & 0.000 & 2.478 & 0.672 & 0.480 & 1.020 & 0.664 & 0.160 \\
\hline & Sp.V. & 0.255 & 0.111 & 0.000 & 2.700 & 0.668 & 0.560 & 0.437 & 0.111 & 0.085 \\
\hline & L.R.V. & 0.052 & 0.034 & 0.000 & 1.225 & 0.850 & 0.495 & 0.085 & 0.034 & 0.000 \\
\hline
\end{tabular}




\section{B-1-Total yield (ton/fed)}

Data presented in figure (7) show consistently obvious differences in the average magnitudes obtained for total yield as well as its components. It was observed that using the two-row planter $M_{1}$ with the bed unit significantly increased the average total tuber yield compared to $\mathrm{M}_{2}$ and $\mathrm{M}_{3}$. For instance, the percentages of increasing rates in Nicola variety were $(6,10)-(9,10)$ and $(6,6) \%$ for the three planting depths 3,5 and $7 \mathrm{~cm}$. Besides, the lowest average values of total yield (ton/Fed) were obtained as increasing planting depth.

\section{B-2-Potato tuber moth infestation, insect damage,}

It is apparent from the same figure (7) that the infected potatoes with tuber moth when planting was achieved by the two-row in bed system is decreased to zero and the yield was nearly free from infected tubers compared to $\mathrm{M}_{2}$ and $\mathrm{M}_{3}$ potato planters especially with deeper planting depths. This result can be seen clearly for the tubers of the three varieties Nicola, Spunta and Lady Rosetta. The average values of the infected potato tubers resulted were $(0.189-0.111-0.0)$; $(0.235-0.074-0.0)$; $(0.052-$ $0.0-0.0)$ ton/fedan as the three planting depths used by $\mathrm{M}_{1}$ respectively. The importance of such parameter is that the potato tuber moth can damage the entire crop later due to their eggs in tubers if existed. An essential fact that, tubers can be infected as they find the way or the reason to go out of the row surface. Therefore, this decrement in infected tubers may be due to the bed system planter $\left(\mathrm{M}_{1}\right)$ which was capable to form the raw surface flat by the attached bedding unit to make a good shape of the bed with removing bigger volume of soil, then the way for the tuber to go out of the surface becomes weaker. Otherwise, when comparing this situation with $\mathrm{M}_{2}$ and $\mathrm{M}_{3}$ potato planters the shape of the planted row takes the normal pyramid form which easy to be destroyed from the top where additional hilling is nesecary during growing process. Potato tuber moth infestation controlled mechanically by such attached bed system will be better for public health, environment and economic point of view.

\section{B-3- Greening}

The average values of greening tubers demonstrated in figure (7) show clearly the effect of the planting method system $\left(\mathrm{M}_{1}, \mathrm{M}_{2}\right.$ and $\mathrm{M}_{3}$ planters) and planting depths from soil surface $(3,5 \mathrm{and} 7 \mathrm{~cm})$. As expected 

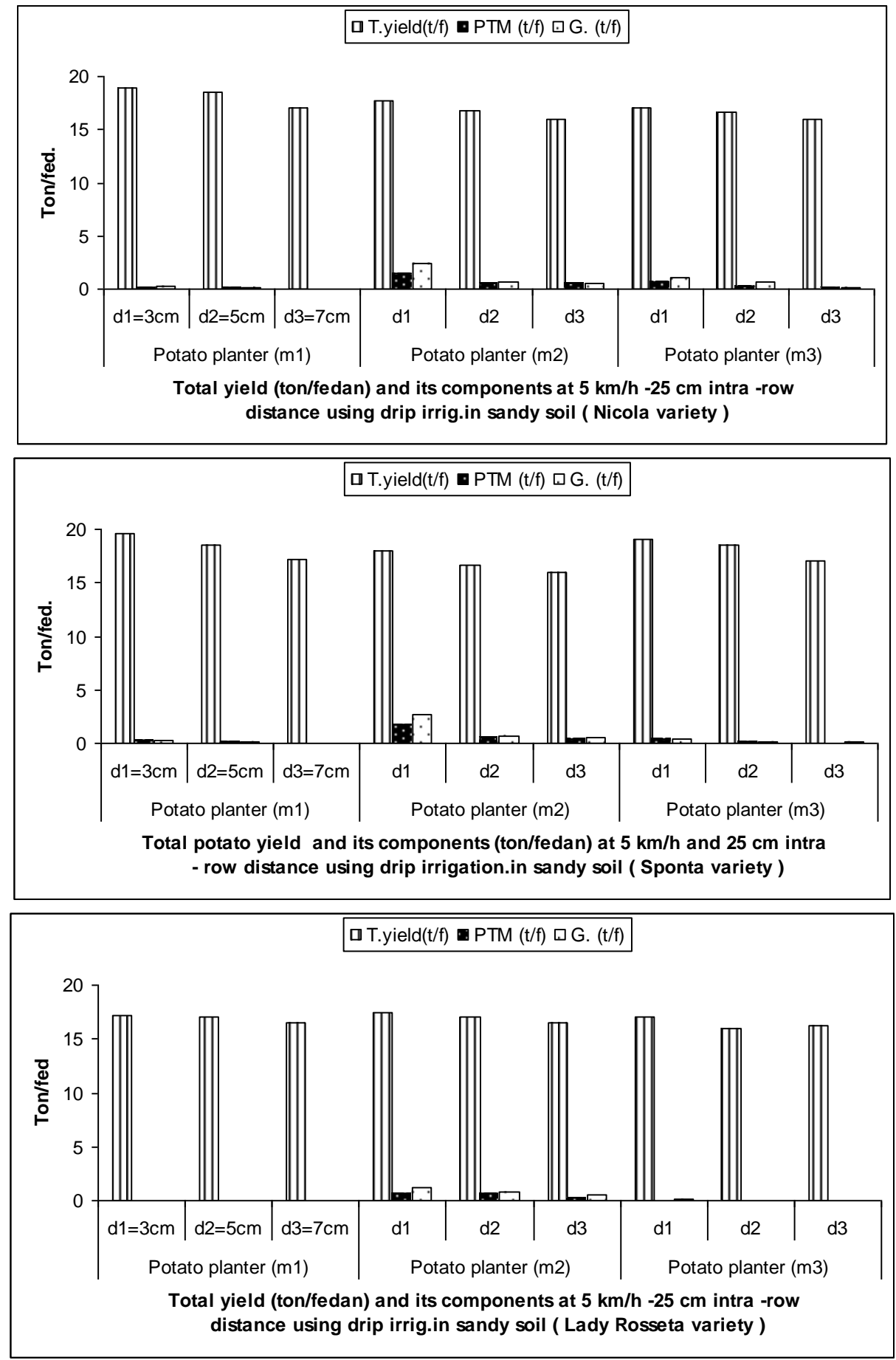

Figure (7): Potato tubers yield and condition 
the calculated percentages of greening tubers with respect to the total yield- generally decreased as seed tubers were planted by $\mathrm{M}_{1}$ with the attached bedding unit (Battana) than by $\mathrm{M}_{2}$ or $\mathrm{M}_{3}$ in sandy soil with drip irrigation application for all potato varieties. According to the calculated percentages of greening tubers related to planter $\mathrm{M}_{1}$, it decreased from 0.25 to 0.0 ; from 0.26 to 0.0 , and from 0.052 to 0.0 ton/fedan as the planting depth increased from 3 to $7 \mathrm{~cm}$ for Nicola, Spunta and Lady Rosetta varieties respectively .

\section{CONCLUSIONS}

The developed potato planter $\mathrm{M}_{1}$ needed lower power than $\mathrm{M}_{2}$ and $\mathrm{M}_{3}$. The specific fuel consumption $(\mathrm{L} / \mathrm{kW}-\mathrm{h})$ obtained at 3.8 to $5 \mathrm{~km} / \mathrm{h}$ planting speed and $5 \mathrm{~cm}$ cultivation depth were $0.41-0.3,0.4-0.3$ and 0.38-0.27 for $\mathrm{M}_{1}, \mathrm{M}_{2}$ and $\mathrm{M}_{3}$ planters. The modified planter $\left(\mathrm{M}_{1}\right)$ recorded the lowest slip ratio which may be because of the effect of Battana for making good stability. The field capacities accomplished using the modified potato planter $M_{1}$, at planting speed of 3.8 to $5 \mathrm{~km} / \mathrm{h}$ and potato planting depth of $5 \mathrm{~cm}$ approached those obtained when practicing $\mathrm{M}_{2}$ and $\mathrm{M}_{3}$ as follows $0.79-72 ; 0.79-0.72$ and0.78-0.72\% for $\mathrm{M}_{1}, \mathrm{M}_{2}$ and $\mathrm{M}_{3}$.

Concerning the productivity of potato tubers yield, infested tubers with moth and green tubers the developed planter $M_{1}$ significantly increased the average total tuber yield compared to $\mathrm{M}_{2}$ and $\mathrm{M}_{3}$ especially at the planting depth of $5 \mathrm{~cm}$ used. Insect damage by potato tuber moth of the yield planted by the bed system planter was nearly disappeared for the three varieties Nicola, Spunta and Lady Rosetta especially at deeper planting depths compared by $\mathrm{M}_{2}$ and $\mathrm{M}_{3}$. It was found that the recorded average values of the infected potato tubers yield by $\left(\mathrm{M}_{1}\right)$ in ton/Fed for the three varieties were $(0.189,0.111,0.0)-(0.235,0.074,0.0)$ and $(0.052,0.0,0.0)$ at depths of $3,5,7 \mathrm{~cm}$.

The observation of the green tubers indicated that the higher planting depth the lower the percentages of related greening tubers. Also the results indicated that developed planter $\left(\mathrm{M}_{1}\right)$ gave the lower averages of greening tubers especially at deeper planting depths compared with $\mathrm{M}_{2}$ and $\mathrm{M}_{3}$. The average values of the green potato tubers resulted by $\left(\mathrm{M}_{1}\right)$ of the cultivars Nicola, Spunta and Lady Rosetta were $(0.2457,0.148,0.0)$ $(0.2548,0.111,0.0)$ and $(0.0516,0.034,0.0)$ ton/Fed at 3,5 and $7 \mathrm{~cm}$ planting depth. 


\section{REFFERENCES}

Abou El- magd A.E. (2001): Potato tuber- soil mutual stress under different machinery treatments. J. Agric. Sci., Mansoura University. ASAE Standards (1992): $37^{\text {th }}$ edition St.Joseph, M1: ASAE.

Awady, M.N, Sahrighi A.F., Hegazi M.M and Hussein A.E (1993): Mechanized rice-transplanting to productivity and economy. Misr J. of Agric. Eng., 10(2):336-350.

Bishop C.F.H. and W.F. Mounder (1980): Potato mechanization and Storage. Chapter 6. Great Britain.

Brown and Keeler (1978): Structure activity relation of steroid teratogens 3. Solanidan epimers. J. Agriculture and Food Chemistry. 26. 566569.

Chmielnicki, J.W. (1988): Effect of the shape of ridges and depth of planting on plant growth, tuber distribution and yields of potatoes. (Part I). Roczniki-Nauk-Rolniczych,-A-Produkcja-Roslinna. 1988 , 107: 2, 85-101; 18 ref .

Ebubekir Altuntas (2005). The Effects of Some Operational Parameters on Potato Planter Performance . Agric Mech. Asia Afr. Lat Am. Vol.36; No.2; Page.71-74(2005)

El-Shal M.S. and shehata M.S. (1987) "Study on the performance of Nardi Potato planter under Egyptian conditions " Misr j. Agric. Eng., 4 (1) :93-98.

El-sheikha m.a .(1989): A quick and effective method to prepare seed bed for Egyptian farms .misr J.agric . eng., 6 (3): 213 - 223.

Hanafi (2004): Sixth Triennial Congress of the African potato Assoc.

Helsel, Z., and T. Oguntunde. 1985. Fuel requirements for field operations with energy saving tips. In Farm Energy Use: Standards, Worksheets, Conservation, ed. C. Myers. East Lansing: Michigan State University

International Center for Potato (CIP) 1993: Periodical bulletin.

Ismail Z. E. (1991): Potato production .Planting, harvesting, handling and storage. Monshaat el Maaref, Alexandria. 
Jadhav \& Salunkhe (1975): Formation and control of chlorophyll and glycoalkaloids in tubers of Solamon tuberosum L. and evaluation of glycoalkaloid toxicity. Advances in Food Research. 21. 307-354.

Jarvis, R.H. and palmer G.M.(1973); Effect of type planter on the growth and yield Expl.Husb.,24:29-36.

Kistanov-EI; Oshurkov-MV (2001): Machine for planting clones. Kartofel'-i-Ovoshchi. 2001, No. 2, 14-15.

Kepner R.A., B. Roy and E.L Barger (1986).Principles of farm machinery $3^{\text {rd }}$ ed. Publishers and Distributors, Delhi 110032 (India).

Mir M. Seyedbagheri (2006). On- Farm Evaluation of Potato Planter Performance. The Idaho Potato Conference on January 18, 2006. Idaho,USA.

Peter R .(1990): On the state of the art in potato planting. Landtechnik. 1990, 45: 5, 174-176.

Petrov G.O. (1984): Potato harvesting machines Moscow machine construction. 1984.

Siemens, J. C., and W. W. Bowers. 1999. Machinery Management: How to Select Machinery to Fit the Real Needs of Farm Managers. Farm Business Management Series. Davenport, Iowa: John Deere Publishing.

Siepmen R.A.M. (1983): Mechanization of potato growing. International course on potato production. Institute of agric. Engineering Waganingen the Netherlands.

Talburt W.F. and O.Smith (1987) " Potato processing forth Edition Van No strand Reinhold company New York; 73-134

Toader V. and Draica C. (1983): Potato planting " an important link in achieving high and constant yields production vegetable,Horticulture. 1983, 32:2, 14-17

Toader V. and Draica C. (1983): Potato planting "an important link in achieving high and constant yields production vegetablehorticulture. 1983, 32:2, 14-17. 
Zaag P. Vander, Demagant A.L. and Vander Zaaq P. (1987): Potato (Solanum SPP) in an isohypothermic environment. Agronomic management field crops research. 17:3 - 4 199-217; 19ref.

\section{الملخص العربي

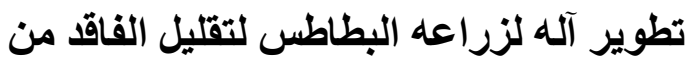 فزاشة الدرنات والإخضر البطار}

د. محمد عبد الفتاح عبد المقصود* د.أحمد حسن جمعة* م.حازم أحمد عبد الفتاح***

تم فى هذا البحث در اسة الاداء لآله مطورة تستخدم فى زر اعة خطين لمحصول البطاطس خلال اجر اء مجموعة دن التجارب الحقلية بمنطقه البستان بالنوبارية وذلك بمقارنة نفس عو امل الاداء

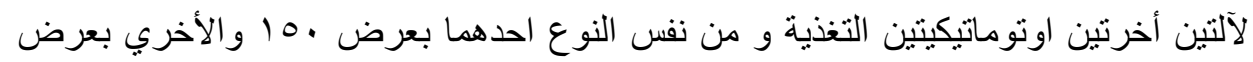

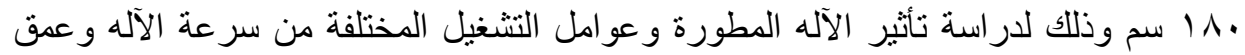
الزر اعة علي انتاجية المحصول ونسبة الإصسابة الحشرية وإخضرار الدرنات. ولقد تم اعداد الأله

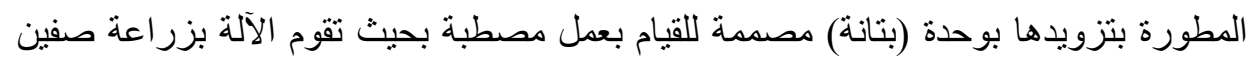

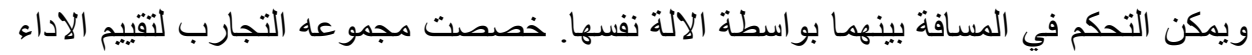

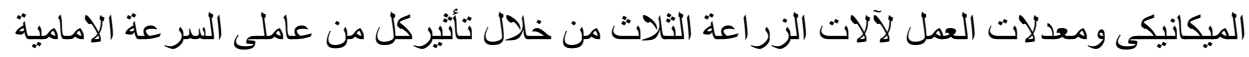

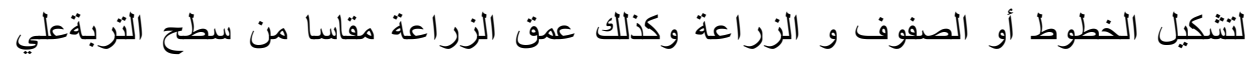

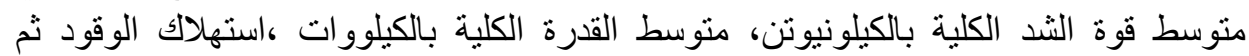

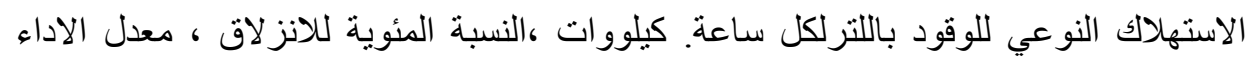

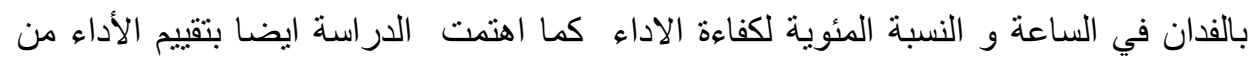

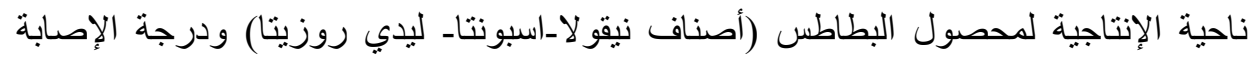

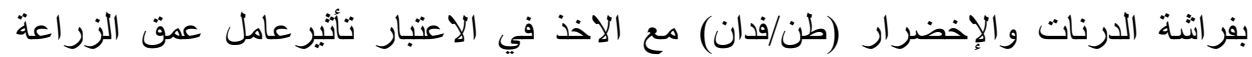
بالاضافة الي إستخدام السرعة المثلى وكذلك أستخدام نظام للري الحديث في نوع من الإند التربة.

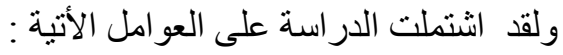

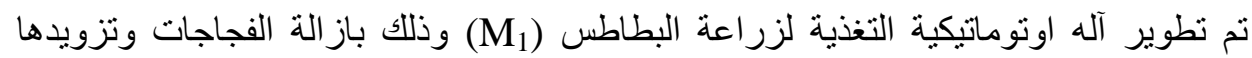

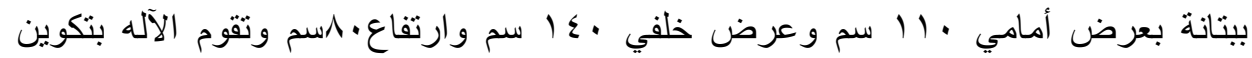

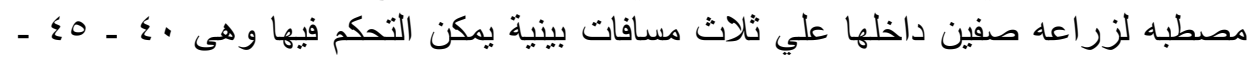

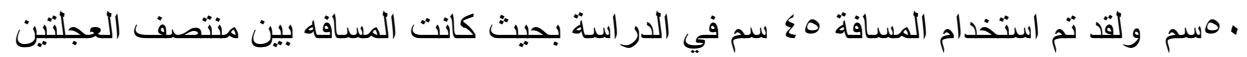
الخلفيتين لها • ـ ا سم. تم مقارنة الأداء للآله المطورة بآلتين اوتوماتيكيتين تقوم كل منهما 9ز بزر اعة خطين بحيث كانت المسافة بين منتصف الخطوط لأحدهماه Vسم (M

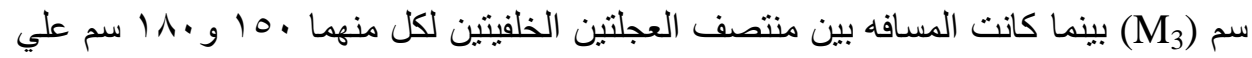
التو الي.

* أستاذ مساعد الهندسة الزراعية قسم الهندسة الزراعية ـ كلية الزراعة - جامعة المنوفيةـ المنوفيةـ مصر

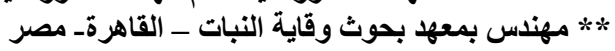




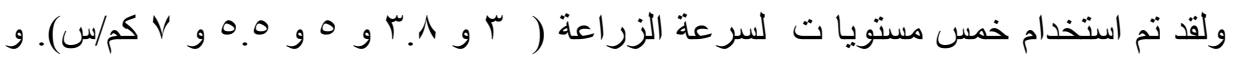
ثلاث مستويا ت لعمق الزر اعة مقاسا من سطح التربة الرملية ( ب و ه و و سم). باستخدام

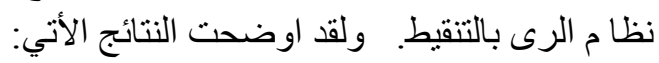
ا- إستخدام الآلة المطورة M1 قد أدى إلى زيادة القيم المتوسطه للناتج الكلى لمحصول

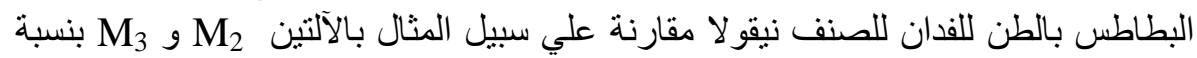

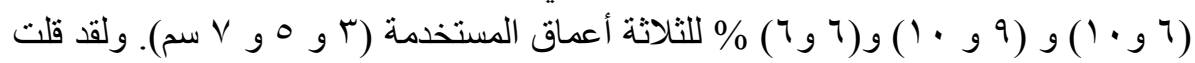

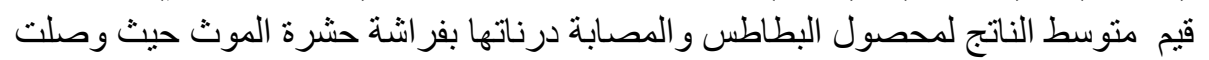

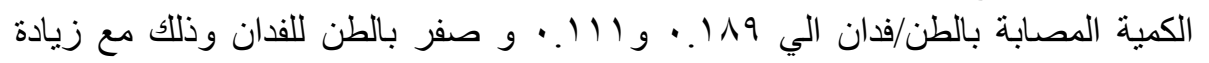

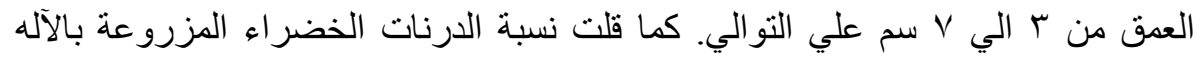
المطورة مقارنة بآلات الزراعة الأخري حيث بلغت القيم المتوسطة للارنات الخضر الثراء



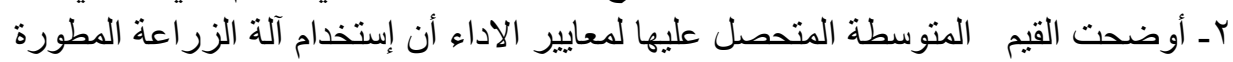
في تشكيل المسطبة و زر اعة صفين بداخلها ان كل من متطلبات قوى الثد والقدرة و

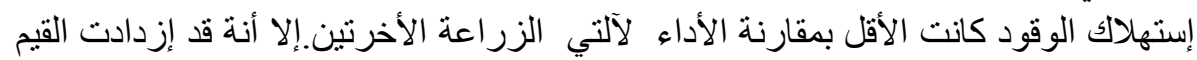

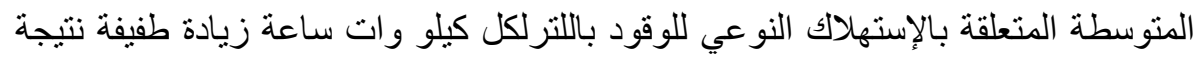

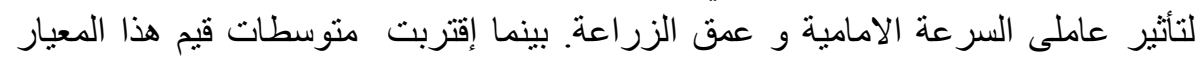

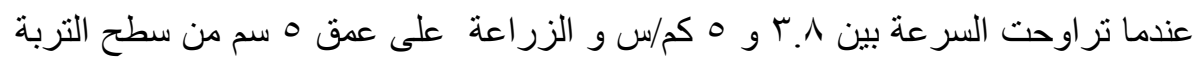
وذللك في الحدود الموصى بها وهذا يتفق مع توصيات

r- تر اوحت القيمة المتوسطة للقدرة الكلية المستخدمة في تشكيل الخطوط أو الصفوف الخاصة

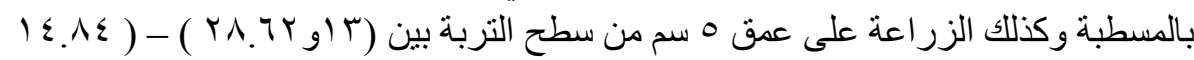

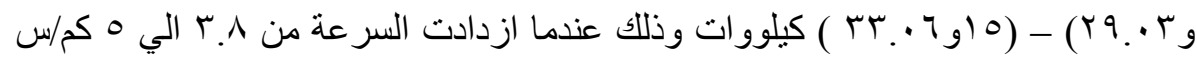

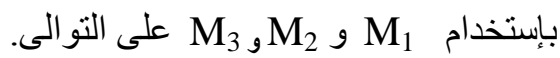

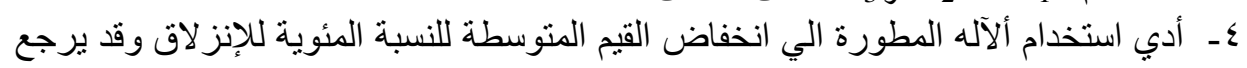
ذلك إلى الإتزان الذى أ ضافة وجود وحدة تكوين المسطبة (البتانة)

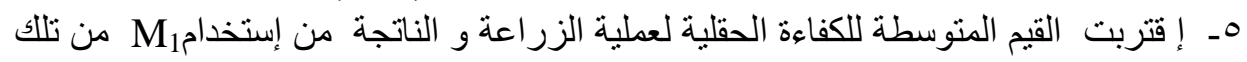

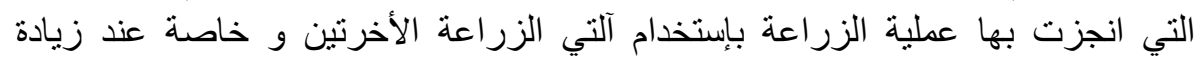

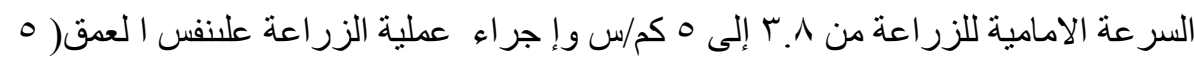
سم ) فقلت من Vף. • إلى الآلات 